慶應義塾大学学術情報リポジトリ

Keio Associated Repository of Academic resouces

\begin{tabular}{|c|l|}
\hline Title & Mutagenicity of alkanediazotates in Chinese hamster V79 cells \\
\hline Sub Title & \\
\hline Author & $\begin{array}{l}\text { 鵜川, さと子(Ukawa, Satoko) } \\
\text { 鮫島, 真砂子(Sameshima, Masako) } \\
\text { 望月, 正隆(Mochizuki, Masataka) }\end{array}$ \\
\hline Publisher & 共立薬科大学 \\
\hline Publication year & 1992 \\
\hline Jtitle & $\begin{array}{l}\text { 共立薬科大学研究年報 (The annual report of the Kyoritsu College of } \\
\text { Pharmacy). No.37 (1992.) ,p.76- 76 }\end{array}$ \\
\hline JaLC DOI & \\
\hline Abstract & \\
\hline Notes & 抄録 \\
\hline Genre & Technical Report \\
\hline URL & https://koara.lib.keio.ac.jp/xoonips/modules/xoonips/detail.php?koara_id=AN00062898-0000003 \\
& $7-0076$ \\
\hline
\end{tabular}

慶應義塾大学学術情報リポジトリ(KOARA)に掲載されているコンテンツの著作権は、それぞれの著作者、学会または出版社/発行者に帰属し、その権利は著作権法によって 保護されています。引用にあたっては、著作権法を遵守してご利用ください。

The copyrights of content available on the KeiO Associated Repository of Academic resources (KOARA) belong to the respective authors, academic societies, or publishers/issuers, and these rights are protected by the Japanese Copyright Act. When quoting the content, please follow the Japanese copyright act. 
No. 37 (1992)

\title{
Mutagenicity of Alkanediazotates in Chinese Hamster V79 Cells*
}

\author{
Satoko Ukawa, Masako Sameshima and Masataka MochizuKI \\ 鵜川さと子，鮫島真砂子，望月正隆
}

We reported different bacterial mutagenicities between geometrical isomers; $(E)$-potassium alkanediazotates were more mutagenic than $(Z)$-diazotates in three microbial strains. This paper describes mutagenicity and cytotoxicity of $(E)$ - and $(Z)$-potassium alkanediazotates in Chinese hamster V79 cells, using ouabain resistance as an indicator.

The cytoxic and mutagenic activity of $(E)$-diazotates decreased with an increase in alkyl chain length; $\mathrm{Me}>\mathrm{Et}>\operatorname{Pr}, \mathrm{Bu}$. On the other hand, $(Z)$-diazotates were less mutagenic and cytotoxic in V79 cells than $(E)$-diazotates. The mutagenicity of $(E)$ diazotates in V79 cells was correlated well to the bacterial mutagenicity and also to the activity to alkylate nicotinamide in an aqueous phosphate buffer. The effects of alkyl group on mutagenicity of $(E)$-diazotates were similar to those of the corresponding $N$-nitroso- $N$-(hydroxymethyl) alkylamines reported, which supports further that $\alpha$-hydroxy nitrosamines decompose through alkanediazohydroxides to alkylate DNA.

These results suggested the geometrical isomerism may influence the carcinogenicity of $N$-nitroso compounds in mammalian include human being.

* 本報告は IARC Technical Report, 11, 120-121（1992）に発表. 